\title{
Recent Sediment Analysis, Study Case: Sub Bottom Profiler Data Line 8 Geomarine Research Vessels
}

\author{
Ulil Amri \\ Study Program of Marine Science, Faculty of Fisheries and Marine Science, Lambung Mangkurat \\ University, Banjarbaru, South Kalimantan, Indonesia
}

\begin{abstract}
North Aru Island's offshore had a long exploration history since 1973 until present. The characteristics of seabed can be studied through the shapes, acoustic reflection pattern, type of substrate or sediment, or by living organisms at the seafloor. In Indonesia, the sub-bottom profiler data was previously only used to measure sea depth. This study was expected to provide overview and updated information about sea depth, seabed and sedimentary layers characteristics based on generated acoustical reflection values and to identify information about abiotic compounding seabed (grain size) used methods Folk 1974 and Spread. Resulted bathymetry data could explain the depth and topography of study areas, seabed characteristics, sea bed sediment classification that were expected to support the determination of shipping tracked lines, underwater pipelines construction, and to determine mineral compounds in the deep sea. The obtained data of field records were in digital *.odc format that is a standard format for BATHY-2010 software. In order to simplify data processing, there would be a series data conversion process into other formats. Data processing of sub-bottom profiling was conducted by Kogeo-imaging software. For more clear and better look than the playback data, the processing data was undergone some steps of treatments such as filtering, stacking and additional gain. Moreover, those data were interpreted at once time with digitizing to interpreted sediment layers. The sea depth of research location was around 52.59-97.03 below the sea surface. Sea bottom formed land (flat) was in the eastern part of the location. Steep basin or Aru Trough was in the western with type substrate of gravelly mud. In general, recorded seismic cut (section) was in the time domain which created vertical velocity distortion and lateral that would produce seismic records that would be different with its actual. Seismic only enabled to detect lithology border if there any acoustical impedance exchange which would be bigger than detectable limit of used seismic waves.
\end{abstract}

Keywords: bathymetry, sub-bottom profile, sediments

\section{INTRODUCTION}

North Aru Island's offshore had a long exploration history since 1973 until present. On some recorded exploration histories, the common failure was no oil charges in ancient sequences (150-200 million years). The consequence of drilling failure directly

Correspondence: Ulil Amri, Marine Science, Fisheries and Marine Science Faculty, Lambung Mangkurat University, Banjarbaru, South Kalimantan, Indonesia (70714). amriuspi@ulm.ac.id affects sea bottom substrates which have function as marine organism habitats. The characteristics of seabed can be studied through the shapes, acoustic reflection pattern, type of substrate or sediment, or by living organisms at the seafloor. The importance of knowing the composition of sea bottom components was to determine sediment distribution patterns based on its size and substrates origins. Sea bottom substrates can be classified based units particle sizes, sources, locations and colors.

Journal of Wetlands Environmental Management

Vol 7, No 2 (2019) 123 - 133

http://dx.doi.org/ 10.20527/jwem.v7.v2.171 
Hydro-acoustic and gravity core are methods that attained to collect information about sea bottom types using transducer, receiver, and gravity core. Hydro-acoustic method also could be applied in sea bottom mapping or bathymetry. In principle, hydroacoustic monitoring is based on a simple work. Sound waves emitted by a generating sound energy device (transducer) in to water column or sea bottom which the device converts previously the energy from electrical energy to mechanical energy. Sound propagation speed in the water column is approximately to 1500 pms-1. When the energy reaches a target, it will be returned in the form of echo, and the echo will be caught by the receiver. Received reflection and backscattering value of the device will be sent to an output device which the mechanical energy previously converted electrical energy previously converted electrical energy and then it gain a digital visualization to be interpreted (Penrose et al., 2005).

The purposes of this study were to get information about ocean depth (bathymetry), interpret profiles and sediment layers beneath the sea floor (seabed) in this case line eight; and to identify information about abiotic compounding seabed (grain size) used methods Folk (Folk, 1974). This study was expected to provide overview and updated information about sea depth, seabed and sedimentary layers characteristics based on generated acoustical reflection values. Resulted bathymetry data could explain the depth and topography of study areas, seabed characteristics, sea bed sediment classification that were expected to support the determination of shipping tracked lines, underwater pipelines construction, and to determine mineral compounds in the deep sea. Hence, underwater acoustic technology could support abiotic underwater marine resources exploration.

\section{MATERIALS AND METHODS}

Sub-bottom profilers are seismicacoustic systems that can detect and image structures buried within the sediments. The three systems most commonly used for high resolution surveying are the boomer, pinger and chirp systems. Whereas the boomer system provides best results for coarser sediments, the pinger and chirp systems deliver greater detail for finer sediments. It is encouraged to use sub-bottom systems in the study of submerged landscapes (Dobrin \& Savit, 1960).

One of instrument used in this method was BATHY-2010 Chirp Sub Bottom Profiler and Bathymetric Echo Sounder. This system was installed in the hull or shipboard. Transducer of sub-bottom profiler type finger consist of small piezoelectric elements that emit short, single and high frequency waves (ranging from $1 \mathrm{kHz}$ to $40 \mathrm{kHz}$ ) when they were activated by electrical impulse. The system produced narrow bandwidth frequency 3.5 $\mathrm{kHz}$. Transducer played a role as a transmitter and receiver. Pinger can only handle low energy pulses (typically 10-60 joules). Low output power combined with narrow frequencies bandwidth produce limited penetration only few meters in sandy sediments, but it reaches approximately 50 meters in muddy sediments (SyQwest, 2010).

The research was conducted in two stages. First, survey and data collecting used Research Vessel (RV) Geomarine III of Marine Geological Institute (MGI) of Ministry of Energy and Mineral Resources 
and acoustic instruments; BATHY-2010 CHIRP Sub bottom profiler and Bathymetric Echo Sounder SyQwest. Then, acoustic data recorded using acoustic sub-bottom profiler devices pinger type.
Sampling of the sediment used gravity core in Northern Wokam Island at Aru Islands (Figure 1). Second, grain size analysis and processing acoustic data by Kogeo-image software.

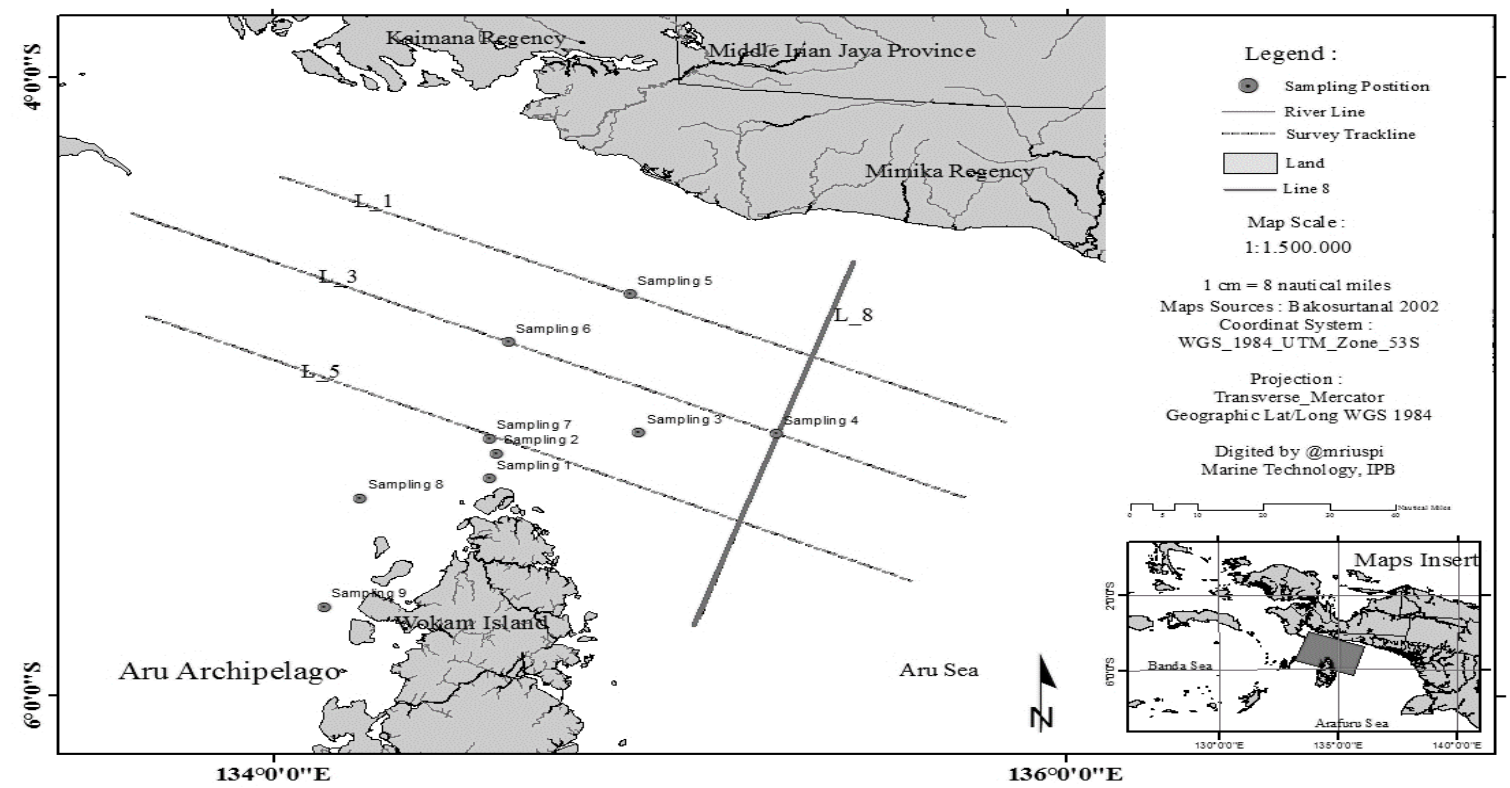

Figure 1. Survey location map, acoustic data recording and sediment core sampling points. L_8 $=$ Track line Survey 8 (thick line)

The ship line were made systematically parallel-diagonal cut in purpose to obtain salutary and represent seabed condition sediments layer data. The study area track lines were Northeast to Southwest and Northwest to Southeast of Aru Islands, (Figure. 1). The sub-bottom profiler was consisted of transducers, console transreceivers and Strata-box software installed at inquisitional computer. The transducer was usually installed on the ship hull, while the trans-receiver console and the computer were installed on the vessel. The strata box software instructs the console trans-receiver to transmit acoustic wave signals and waves will be reflected by the layers in the bottom of the sea until the energy runs out. The reflection of the seafloor layers will be received by the trans-receiver console which then be transmitted to the strata box software in the form of a digital signal and transformed become an image. In data acquisition activities, sub bottom profiler is equipped with DGPS position determinants and navigation software to guide the survey nets to match the planned line 8 .

The obtained data of field records were in digital *.odc format that is standard format for BATHY-2010 software. In order to simplify data processing, there would be a series data conversion process into other formats. Data processing of sub-bottom profiling was conducted by Kogeo-Imaging software. For clearer and better interpretation of the playback data, the processing data was undergone some steps of treatments such as filtering, stacking and additional gain. Moreover, those data were 
interpreted at once digitized to describe the sediment layers using Damuth classification scheme methods (Damuth, 1980). Flow- chart of data processing sub-bottom profiler was shown at Figure 2.

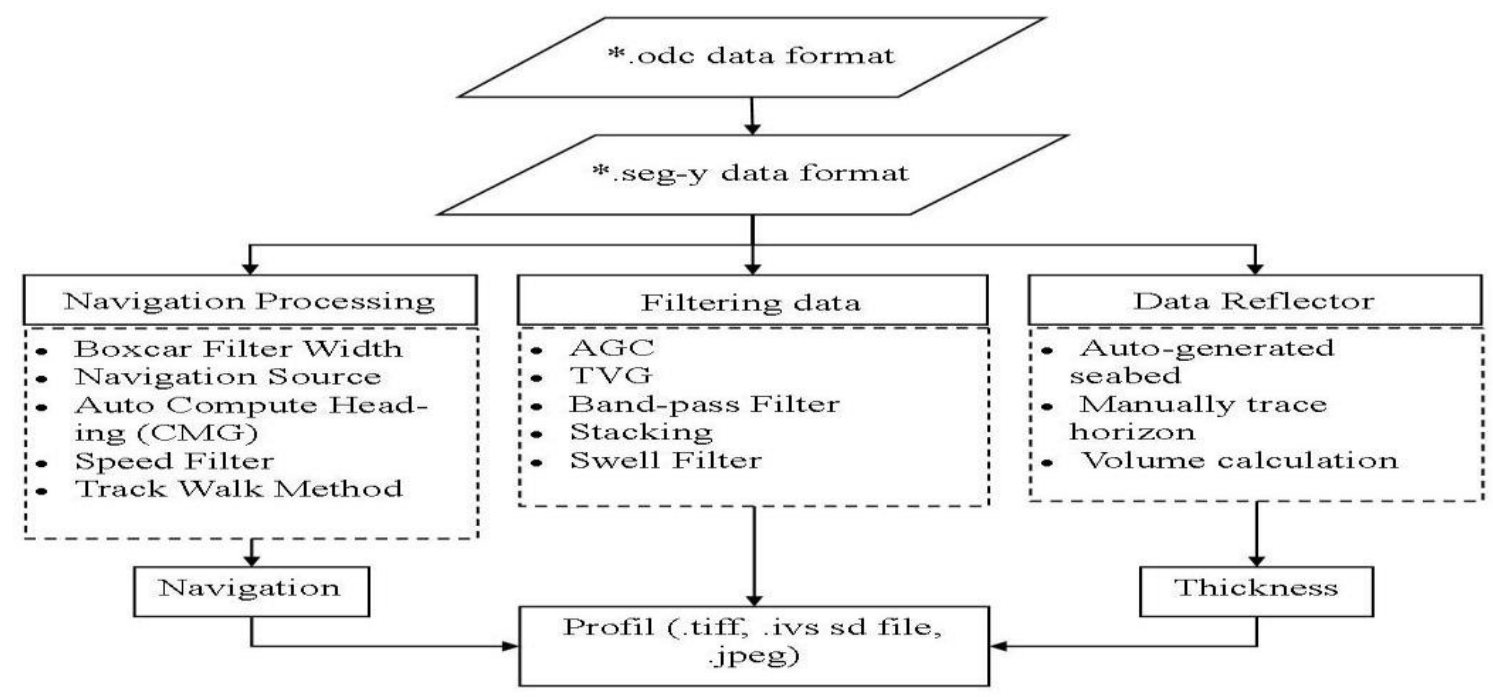

Figure 1. Flow-chart of Sub-bottom profiler data processing

Digitation process result were data reflector X (latitude), Y (longitude), and Z (depth) which will be used to determine the depth of study area. Those depth data were used to representing seabed surface relief conducted by simple nearest neighborhood interpolation to avoid significant magnitude deviation (Bresnahan \& Dickenson, 2002). The simple nearest neighborhood interpolation is method using closest points to generate values on the grid nodes. This mechanism is useful to convert the distances permanently for $\mathrm{XYZ}$ data file into the grid. This method did not extrapolate $\mathrm{Z}$ values exceed the distance of those both grid data. As result seabed floor was formed which will be overlaid along with SRTM data (Amri, 2016). Bathymetry survey basic principle using acoustic is to detect then capture the time different reverberation (echo) of vertical orientation pulses. This pulses detection is varied each system, but basically depend on the minimum intensity limit (threshold) and peak width (pitch width) (Sabol, Kasal, \& Melton Jr, 1998). This bathymetry survey was generated by navigating direction and time pulse echo (echo) of the sea bottom depth. The sediment sampling was undertaken on nine point stations. These numbers of stations were expected represent the seabed. These samples served as a control for the seafloor based on the acoustic system reflection. Sediment sampling used gravity cores (Amri, 2016) (Figure 3). 


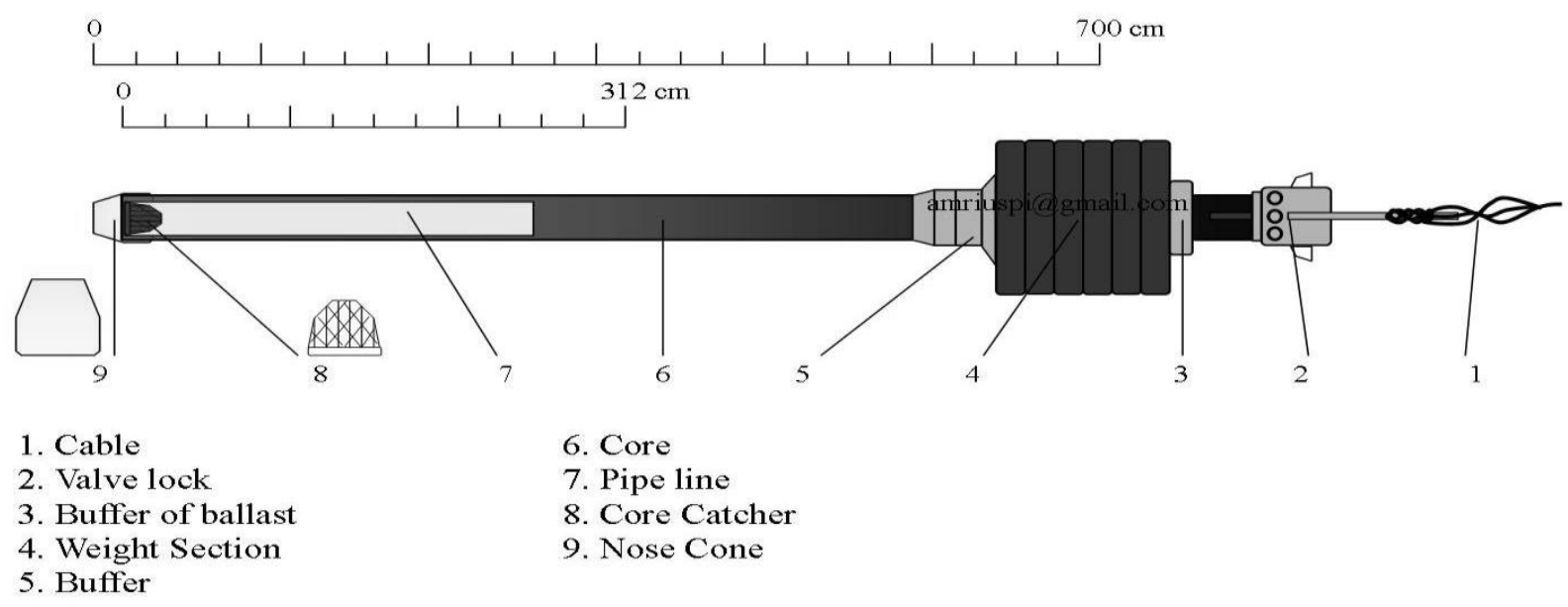

Figure 2. Diagram of Gravity Core

Sediment layers external shape and internal texture of sub-bottom profiler cross section records conducted using seismic facies analysis. This analysis was to determine environmental depositing of seismic reflection characteristics (continuity of amplitude, velocity, frequency and phase).

\section{RESULTS AND DISCUSSION}

\section{Bathymetry}

The survey using RV Geomarine III obtained patch length as long as $81.2 \mathrm{~km}$ and one sediment core sampling. Based on acoustical data records, the water depth was in ranged of 15 to $3,703.23$ meter. The Wokam northern island water was divided into two sections, the east and west part. The eastern part is in ranged of 15 to $337.19 \mathrm{~m}$, and the west one 37 to $3,703.23 \mathrm{~m}$ under the sea mean level with interval contour was 600 m. The survey using RV Geomarine III obtained patch length as long as $81.2 \mathrm{~km}$ and one sediment core sampling. Based on acoustical data records, the water depth was in ranged of 15 to $3,703.23$ meter. The Wokam northern island water was divided into two sections, the east and west part. The eastern part is in ranged of 15 to $337.19 \mathrm{~m}$, and the west one 37 to $3,703.23 \mathrm{~m}$ under the sea mean level with interval contour was 600 m.

This research result a significant morphology difference in the study area (Figure 4). Seafloor morphology (Figure 4b) in the eastern part was relatively flat and the western part was drastically to be deeper and steeper which was known as Aru Trough. Geologically, the area of study was laid in the Northern Sahul Shelf. A numerous of closure topographic pattern (closures) in the shallow water below 100meter depth under sea mean level were interpreted on the western part of the research location. The closure did not indicate a prominent altitude because the depth difference between eastern and western part of the study location was significant. 


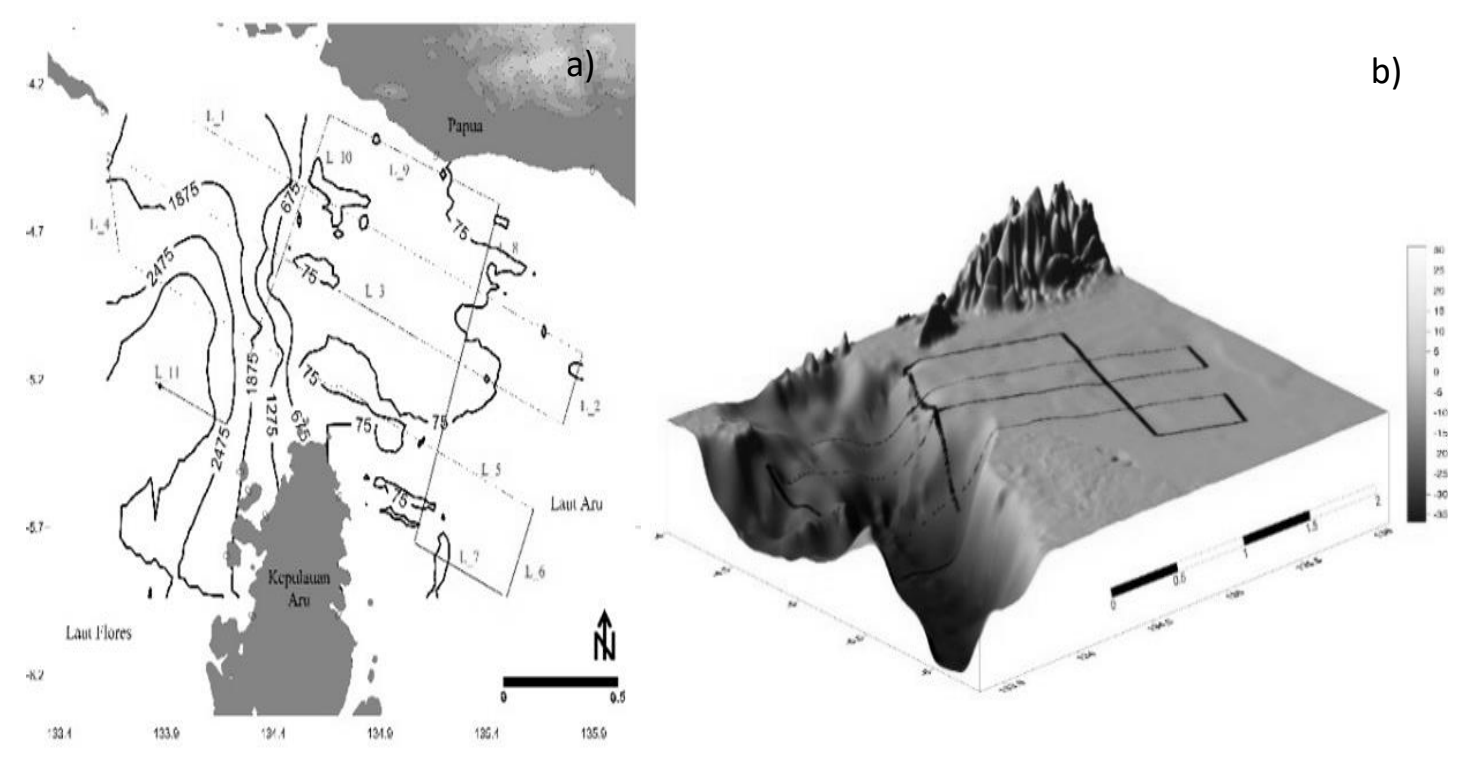

Figure 3. Depth Maps of Northern Wokam Island, Aru archipelagos; a) 2-D northern Wokam Island depth map (Source: SBP data records); b) 3-D depth of northern Wokam Island (source: SBP data records were integrated with shuttle radar topography mission database).

Arafura seafloor is a vast shelf, around 1.5 million $\mathrm{km}^{2}$. (Nontji, 2005) described this shelf consisted of three parts such as Arafura shelf $\left(930.000 \mathrm{~km}^{2}\right.$ width), Rowley shelf and Sahul/North Australia shelf $\left(300.000 \mathrm{~km}^{2}\right.$ width). The Arafura shelf had 30-100 m depth and consisted of Aru Islands which were composed of five islands and each of those islands was separated by narrow straits. An unsure ridge longed from Aru Islands toward eastern part of the shelf that it was called as Merauke Ridge. In Pleistocene aged, when the sea water surface was low, the islands merged to Papua main land. While either Aru Islands or Kai Islands had not merged even those islands were near each other. It happed because there was a bar called Arun Basin that had more than 3,000meter depth between those both chained islands.
In mineral genesis point of view, the condition around Aru Shelf was affected by younger tectonic activities. Compression forces suppressed from northeast to southwest of the shelf area that happed on Eosin era (42 million years ago) formed Aru Shelf. On mezosoikom age straighten from northeast to southwest result forming graben structure and Half Graben which clearly emerged as Aru Trough. This tectonic activities still continue until now and the straitened toward northeast to form graben structure and it have been proved in the Lengguru structure on the neck of Papua Island (Wijaya et al. 2014).

\section{Core Sediment Analysis}

Line $8 \quad\left(5^{\circ} 09^{\prime} 22.563 " \mathrm{~S} \quad\right.$ and $\left.135^{\circ} 16^{\prime} 15.133^{\prime \prime E}\right)$ had one core sediment sample. Core sampler total length was 312 
$\mathrm{cm}$ with sediment core length was $9 \mathrm{~cm}$ and $74.5 \mathrm{~m}$ under sea surface. The large grain fractioning was conducted to determine its mean, sorting, skewness, and kurtosis. Granulometric analysis was carried out to determine sediment names and grains sand (-2 phi to 4 phi) was carried out using dry sieve method with 0.5 phi sieve interval, while the separation of silt-clay size (5 phi to 9 phi) was carried out by pipette method.

Results of the weight analysis from $100 \mathrm{gr}$ origin sample, cumulative weight 98.3794. Grain size of each mesh as follows: -1.5 phi $=5.1677 \mathrm{~mm},-1.0 \mathrm{phi}=0.3425 \mathrm{~mm},-0.5 \mathrm{phi}$ $=0.1819 \mathrm{~mm}, 0 \mathrm{phi}=0.2241 \mathrm{~mm}, 0.5 \mathrm{phi}=$ $0.5387 \mathrm{~mm}, 1.0 \mathrm{phi}=0.4722,1.5 \mathrm{phi}=$ $0.4940 \mathrm{~mm}, 2.0 \mathrm{phi}=0.5376,2.5 \mathrm{phi}=$ $0.3424 \mathrm{~mm}, 3.0 \mathrm{phi}=1.4100 \mathrm{~mm}, 3.5 \mathrm{phi}=$ statistical parameter of sediment based Wentworth scale's (Wentworth, 1922). The result of grain size analysis describe as phi scale, started from -2 phi up to 9 phi. Separation of the fraction size of gravel to

$1.5333 \mathrm{~mm}, 4.0$ phi $=0.1474 \mathrm{~mm}$. Pan 86.9876 , pipette weight of $20,000 \mathrm{ml}$, at 4.0 phi $=0.8161 \mathrm{ml}, 5.0 \mathrm{phi}=0.6145 \mathrm{ml}, 6.0 \mathrm{phi}$ $=0.1140 \mathrm{ml}, 7.0 \mathrm{phi}=0.0531 \mathrm{ml}, 8.0 \mathrm{phi}=$ $0.0295 \mathrm{ml}$. Statistical parameter and type of sediment analysis resulted $\mathrm{x}$ value $(\mathrm{phi})=$ 4.6 , sorting $=1.9$, skewness $=1.8$, kurtosis $=$ 7.0 , gravel $=6.3$, sand $=6.3$, silt $=86.1$ and clay $=1.6$. According to Folk (1980) those kinds of sediment were named muddy gravel. The description of physical and chemical (lithology) characteristics of the taken samples were depicted in the Figure 5.

\section{Core Sample}

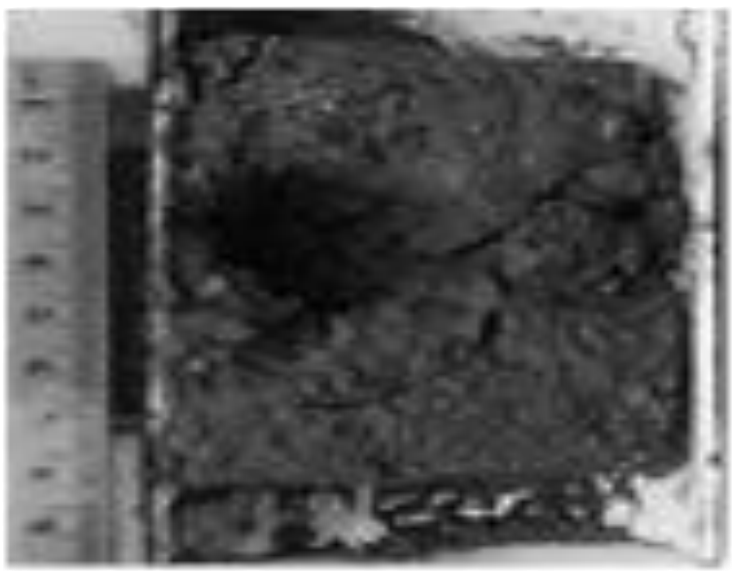

\section{Scale Lithological}

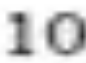

Figure 4. The litological sea bottom sediment sample section in the coordinat of $5^{\circ} 09^{\prime} 22.563$ 'S and $135^{\circ} 16^{\prime} 15.133$ 'E. 0-9 cm : very fine sand consisted of silt, gravel, greenish brown $4 / 2$, biogenic shell fragments $( \pm 15 \%)$, gritty sediment up to $<0.5 \mathrm{~cm}$. The gravel consisted of brown sedimentary rock fragments sized was up to $\pm 6 \mathrm{~cm}$ and forming angles. 


\section{Profile Reflection and Its Interpretation}

Data of Echo-sounder SyQuest Bathy 2010 with frequency $3.5 \mathrm{kHz}$ had been processed and filtered. Moreover, it displayed trajectory image per segment, and all integrated segments went to be full image and also finalizing sub bottom profiler full section of each trajectory. The distance of sounding transducer at the vehicle toward seafloor and layers was $200 \mathrm{~m}$. Depth penetration that can provide detailed watersheds and sediment layers in the range of $75 \mathrm{~m}$ to $90 \mathrm{~m}$ or thickness up to $15 \mathrm{~m}$. Profiler pinger type was designed specifically for certain but for significant water depths and the bottom penetration of the water frequency used starts from 12 or more often $3.5 \mathrm{kHz}$ (Damuth, 1980). Operating of sub-bottom profiler pinger type with frequency $3.5 \mathrm{kHz}$ usually result penetration of 10-15 m depth layers and its resolution was under $0.2 \mathrm{~m}$ depended on the type of sediments (SyQuest, 2010). The reflection profile generated by the $3.5 \mathrm{kHz}$ sub bottom profiler is illustrated in Figure 6.

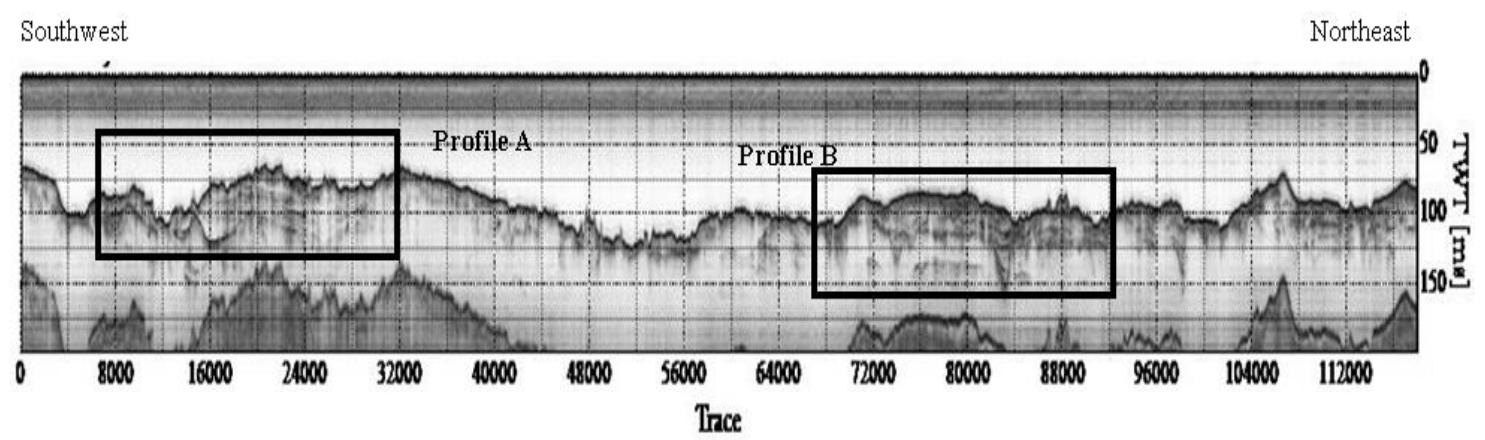

Figure 5. Profile Sub-Bottom Profile Trajectory 8. Above) Initial data of sub-bottom profiler resulted records after conducting band-pass filtering on the range of 1000-60 Hz, Automatic Gain Control (AGC) and Time Varying Gain (TVG) was $0.15 \mathrm{~dB} / \mathrm{m}$; Down) Data of subbottom profiler resulted records after conducting Predictive Deconvolution Method with prewhitening $5 \%$ on 150 samples and the distance accuracy was 1-2 trace.

Seismic interpretation is greatly varies, ranging from interpretations of regional studies to detailed reservoir studies thus is very difficult to formulate standard objectives and procedures, unless this paper the interpretation is intended to provide an overview of sediment layer based on the reflection of the received sub-bottom profiler signal. This seismic interpretation process included picking horizon analysis on the layer of Near Base Miocene, Top Miocene, Top Pliocene and pulling structured lines. In general, data quality of subbottom profiler on the research area classified as less outstanding and commonly the continuity reflector was difficult to be observed. Dividing type of reflector into a collision contact of unconformity must be found among connected reflector groups (Sangree \& Widmier, 1978). The unbalanced contacts in the stratigraphy seismic could be erosional truncation, on lap contact and a strong reflector and perpetual. Some steps were conducted in interpreting seismic records as below:

- Seismic sequence analysis, by dividing seismic section into several guides based 
on the "boundary sequent" in the form of erosion or on lap contact;

- Facieses analysis, which divides seismic collections in seismic sections into several sub-collections based on the internal reflector;

- Analysis of internal reflector characters, can be used to interpret the sedimentation system and depositional environment.

Interpretation results of sub bottom profilers on trajectory 8 divided into two profiles (Figure 7 Profile A and Figure 8 Profile B), each was enlarged to ease digitize.

\section{Analysis of Profile A and B Based on Seismic Facieses Analysis}

After the track profile 8 Figure 6 deconvolved $5 \%$ of 150 samples with a detail level of 1: 2 then seismic facies analysis of 2 parts was carried out. The selected part (profile A and profile B) as a reference for the sediment layer was considered to provide information on various depositional environments. Seismic waves that penetrate and are reflected back to the surface will portray the shape of the sedimentary layer. Distance trace A profile taken from trace 800 to trace 32000 if converted into kilometers as far as 1.1503 $\mathrm{km}$ long. Profile A enlarged X $45 \%$ and Y $550 \%$ can be seen in Figure 7. Profile B started on the trace 64000-92000 which displayed as follows (Figure8).

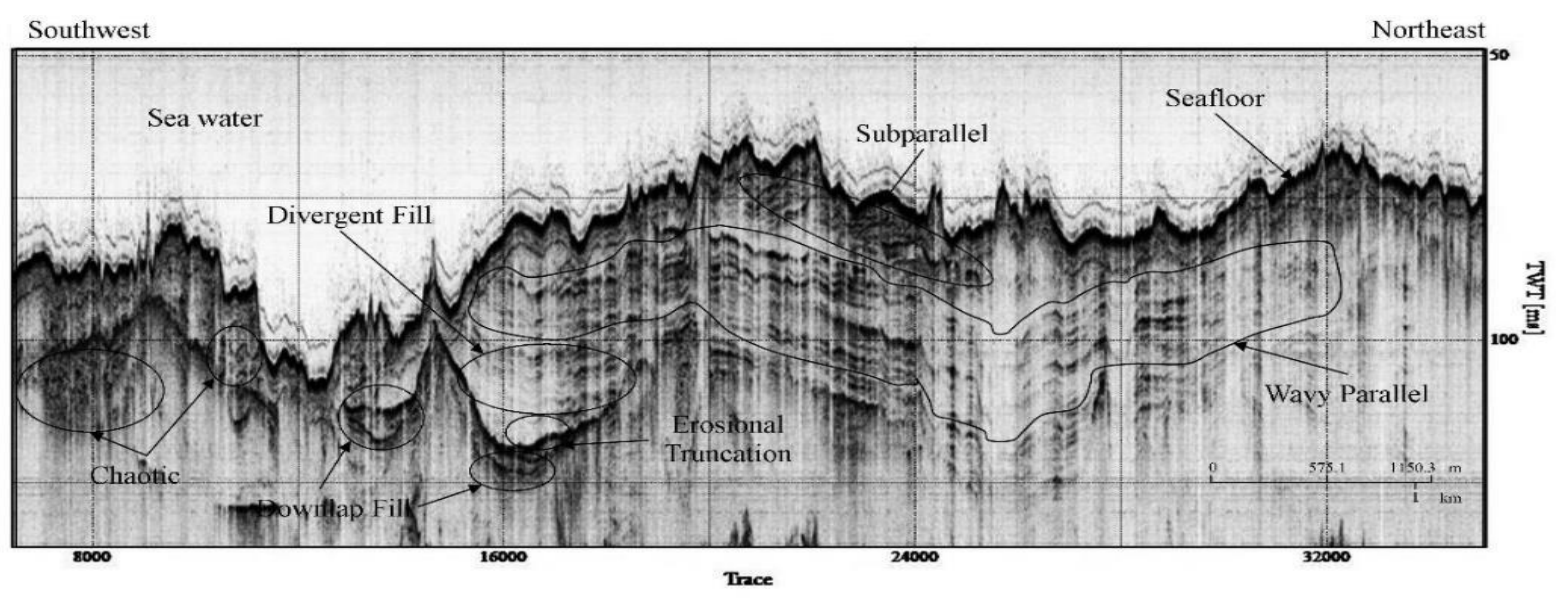

Figure 6. Profile A, Zooming X 45\% and Y 550\%

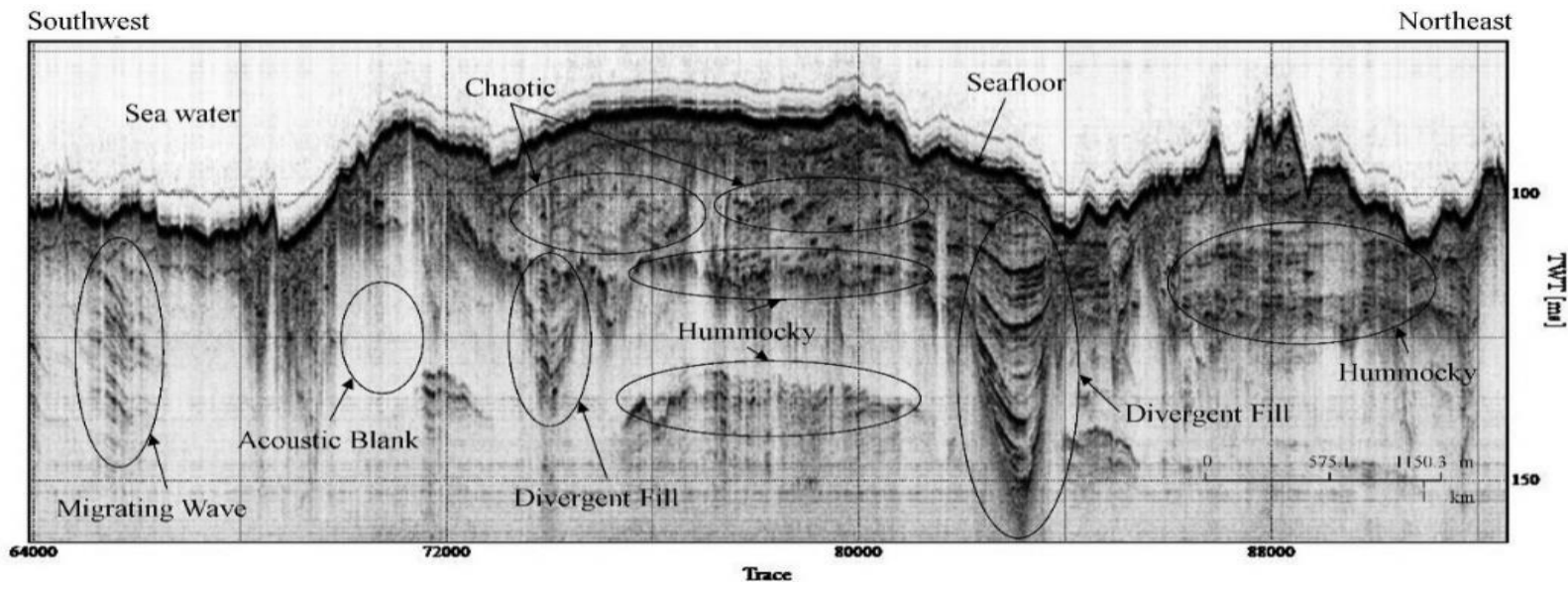

Figure 7. Profile B at Zooming X 45\% Y $550 \%$ 
Facies identification of the A profile found 6 types that are: chaotic, downlap, divergent fill, subparallel, parallel wavy and erosional truncation.

1. Chaotic is an internal deposition texture with high energy (mounding, cut and fill channels) or deformation after the sedimentation process (faults, overpressure shale movements, etc.).

2. Downlap is the lower limit of the seismic sequence caused by intense sedimentation;

3. Divergent Fill is channel filling texture on hale prone which is compacted with low energy sedimentation, as well as typical of the final stages of filling graben;

4. Sub-parallel, internal texture layers are formed in the filling zone, or in situations that are disturbed by ocean currents;

5. Wavy parallel, an internal texture formed due to compression folds from a parallel layer above the detachment surface or flanked or sheet drape with fine grained deposits;

6. Electronic truncation or called the unconformity (unbalancing) was affected by erosion activities as it's exposed to the surface.

The result of facieses identification found on profile B were four types of facies such as migrating wave, divergent fill, chaotic, and hummocky. Their process were described below.

Migrating wave : sediment layers due to sea bottom current;

Divergent fill : compacted shale prone with low energy sedimentation and also as last typical phase of graben filling;
Chaotic : High energy sedimentation (mounding, cut and fill channel) or deformation after sedimentation process;

Hummocky : formed on shallow areas. It was characterized between delta and middle energy;

\section{Profile A and B Analysis Based on Acoustical Reflection Analysis}

Unit characters of seismic reflection recordings allow to direct application of geological concepts based on the stratigraphic physical appearance of the recording. Seismic wave primary reflection occurs due to acoustic impedance differences (wave velocity $\mathrm{x}$ density) from the rock surface and or discontinuity or unconformity fields. Hence, all rock layers that lie above a layer or alignment plane are younger than those located below it, the seismic cross section is a chrono-stratigraphic record of the structure pattern and deposition pattern, and is not a lithostratigraphic record.

The type of relationship between seismic reflection and geological time lines identified in a seismic section, as follow:

- Reflection - seismic reflection that follows aligned geological time lines and can be a plus or minus of half wavelengths (Peak \& Trough);

- Discontinuity - discontinuities of seismic reflection, such as: unconformities and down-lap surfaces that generally follow geological time limits;

- Poor appearance seismic reflections, which are caused by fluid interfaces and the presence of certain diagenetic changes that also follow the diachronus surfaces of geological time; 
- Seismic reflections, mainly produced by the surface layers and lower boundaries of a layer such as non-alignment and downlap surfaces, observe by matching velocity-density contrast caused by interconnected reflections.
Hiatus duration is related to a lower boundary of a layer that can change, while the lower limit of a layer is a geological time limit because it separates rocks with different geological ages and not overlapping with other chromosstratigraphic surfaces.

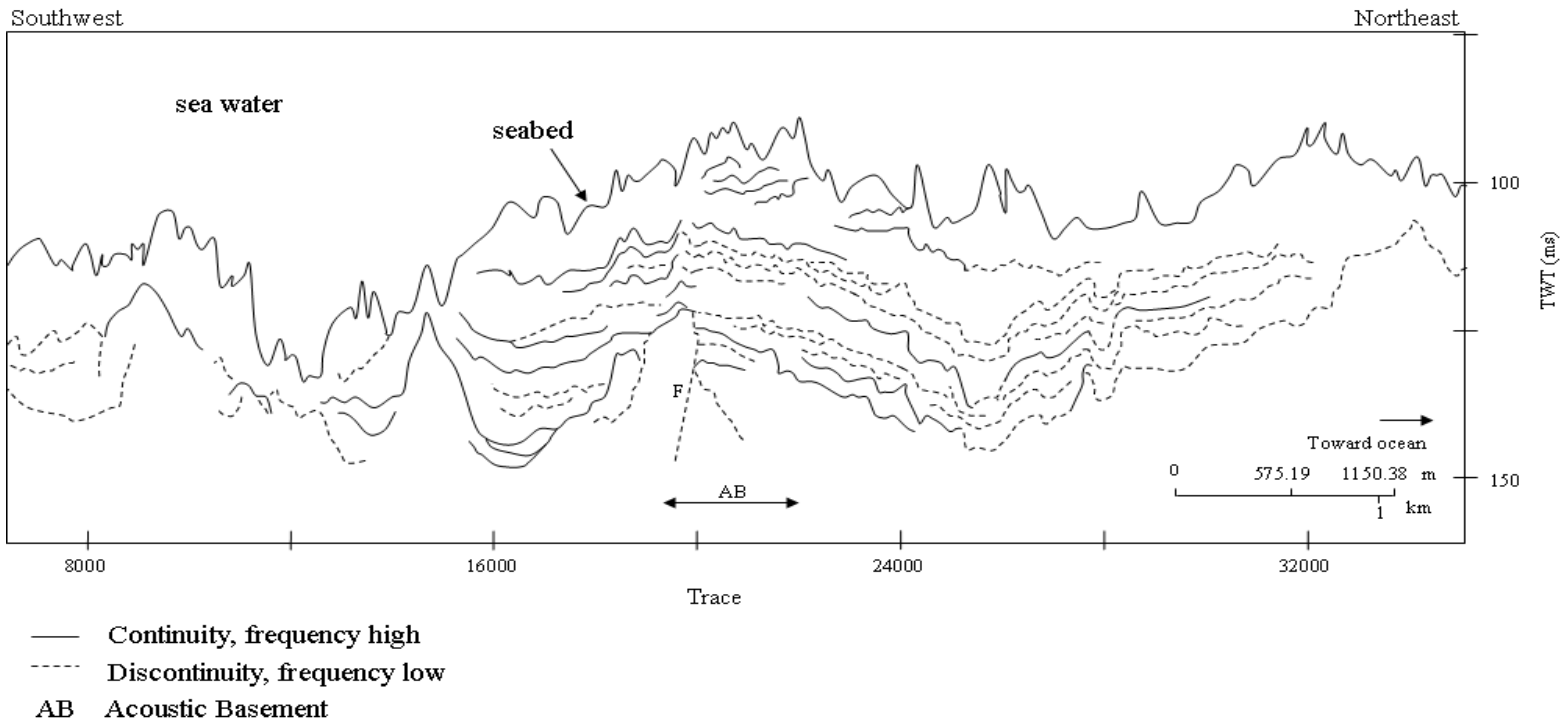

Figure 8. Acoustic Reflective Pattern of Profile A

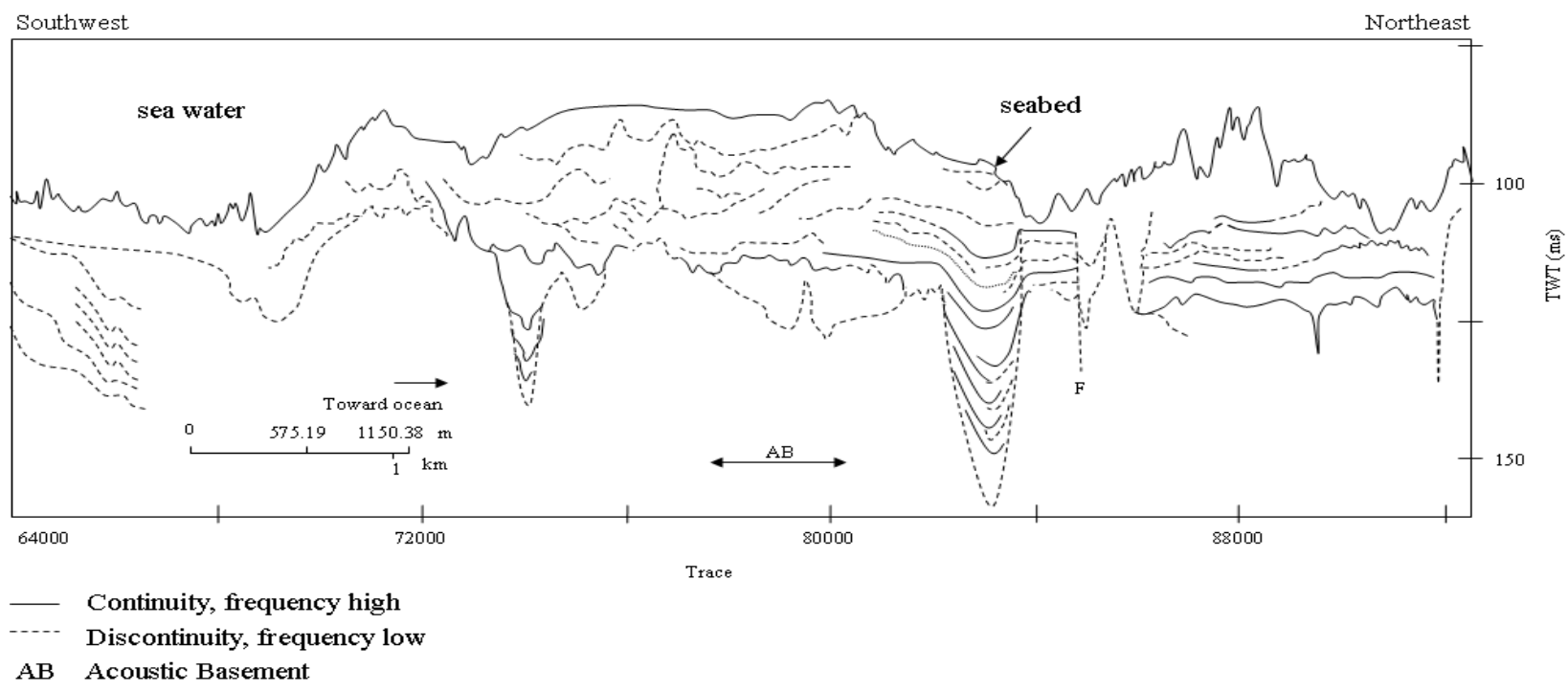

Figure 9. Acoustic Reflective Pattern of Profile B

Both figures above (Figures 9 and 10) sediments formed are dominated by showed black and white acoustic reflective discontinuity reflection patterns (lack of pattern with scale 1: $1150.3 \mathrm{~m}$. Profile A continuity) very few patterns of continuity are explains regular acoustic reflections, found. The discontinuity pattern indicates that

Journal of Wetlands Environmental Management

Vol 7, No 2 (2019) 123 - 133 
the received frequency is low, while continuity indicates a high frequency. In Profile B there is little difference from Profile $A$ that the existence of a basin due to a fracture or shift between layers/ deposits. This profile B was dominated by discontinuity patterns.

Collaborating sub bottom profiler recordings and sediment core data is intended to determine the position of the core. A reflector is observed and digitized carefully based on the level of detail / line formed. Giving a line is based on the presence of striking differences between layers. Clarity of the first reflector line is considered as the boundary line between the water column and the surface sediment layer is considered as the top seabed (purple) and the second line is considered as the second more compact sedimentary layer (green) (Figure 11).

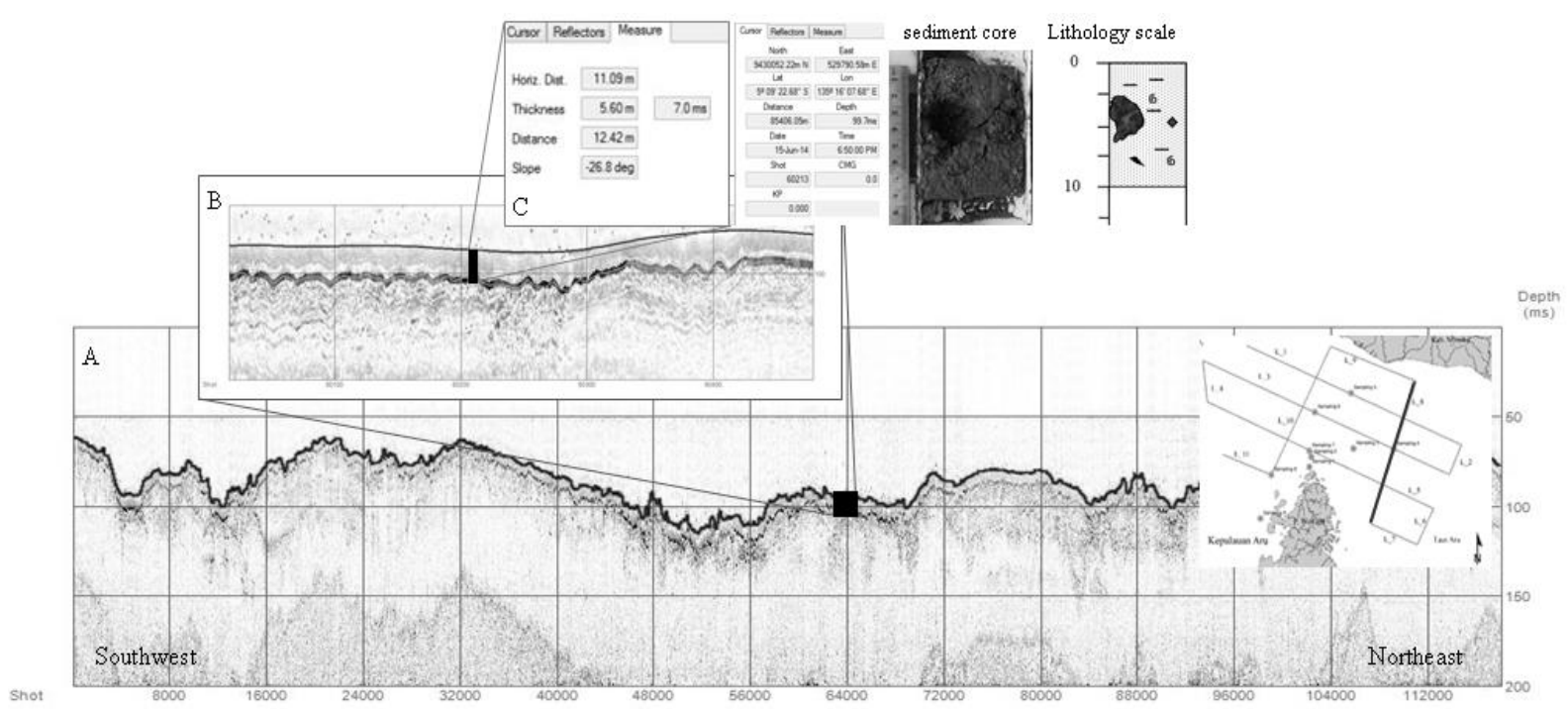

Figure 10. Profile of the Trajectory 8 with the Integration of Poled Coring Position; a) Core position was marked with black box; b) Core sediment which had been parted and identified;

c) Acoustical wave spectrum on coring location.

\section{CONCLUSION}

The sea depth of research location was around 52.59 - 97.03 meter below the sea surface. The seabed is flat in the east and there is a steep basin or Aru Trough on the west with a type of gravelly mud substrate. Steep basin or Aru Trough was in the western with type substrate of gravelly mud. The sediment layer in profile $\mathrm{A}$ is dominated by fine-grained sediments, and profile $\mathrm{B}$ is dominated by sedimentation deformation. In general, seismic cross sections are recorded on a time domain, causing vertical or lateral velocity distortions that will produce seismic record that is different from the actual geological conditions. Seismic is only able to detect lithological limits if there is an acoustic impedance change (AI) which is greater than the detectable limit of the seismic waves. Because of the limited ability of the sub-bottom profiler data processing software used (KOGEO), the echogram displayed was low-resolution and lack detail, in the future data processing software providers are expected to upgrade program capability in data interpretation.

\section{ACKNOWLEDGMENT}

The authors would like to thanks the Head of the Bandung Marine Geology Research and Development Center, the chairman and 
team of scientists, technicians, captains and crew members of KR Geomarine III for providing survey data to complete this paper. Thank's to Mrs. Meri Afiza for providing language help and proof reading the article.

\section{REFERENCES}

Amri, U. (2016). Integrasi Data Sub Bottom Profile Dan Gravity Core Untuk Menentukan Dinamika Sedimentasi Resen Di Perairan Utara Wokam. [tesis]. Bogor: Agricultural University (IPB).

Bresnahan, T., \& Dickenson, K. (2002). Surfer 8 self-paced training guide. Golden Software Inc.

Damuth, J. E. (1980). Use of high-frequency $(3.5-12 \mathrm{kHz})$ echograms in the study of near-bottom sedimentation processes in the deep-sea: a review. Marine Geology, 38(1-3), 51-75.

Dobrin, M. B., \& Savit, C. H. (1960). Introduction to geophysical prospecting (Vol. 4). McGraw-hill New York.

Folk, R. L. (1974). Petrologie of sedimentary rocks. Hemphll Publishing Company, Austin, 170. https://doi.org/10.1017/CBO9781107415 324.004

Nontji, A. (2005). Laut nusantara. ed. rev. cet. 4. Djambatan. Jakarta.

Penrose, J. D., Siwabessy, P. J. W., Gavrilov, A., Parnum, I., Hamilton, L. J., Bickers,
A., ... Kennedy, P. (2005). Acoustic Techniques for Seabed Classification. Cooperative Research Centre for Coastal Zone Estuary and Waterway Management, (September), 141.

Sabol, B. M., Kasal, R. L., \& Melton Jr, R. E. (1998, September 8). Method and apparatus for hydroacoustic detection and characterization of submersed aquatic vegetation. Google Patents.

Sangree, J. B., \& Widmier, J. M. (1978). Seismic stratigraphy and global changes of sea level, part 9: seismic interpretation of clastic depositional facies. $A A P G$ Bulletin, 62(5), 752-771.

SyQwest, I. (2010). Bathy $2010^{T M}$ CHIRP Sub Bottom Profiler and Bathymetric Echo Sounder (Operation). Warwick. Retrieved from http://www.syqwestinc.com

Wentworth, C. K. (1922). A scale of grade and class terms for clastic sediments. The Journal of Geology, 30(5), 377392.

Wijaya PH, Lugra IW, Astawa N, Surachman $M$, Kristanto NA, Wahib A, Ilahude D, Hardjanto BT, Setiady D, Hermansyah $G$, et al. 2014. Potensi Migas dan Kaitannya dengan Lokasi Perangkap di Wokam-Aru Utara, Papua Barat untuk Mendukung Penyiapan WK Migas Nasional [Laporan Akhir Survei Geomarin III]. Bandung (ID): Pusat Penelitian dan Pengembangan Geologi Kelautan 